\title{
Developing Pictographic Impact on the Minds of the Students through Poetry of John Seely's Textbook Taught at O'level in Pakistan
}

\author{
Abid Hayat Khokhar (Corresponding author) \\ Majmaah University, Saudi Arabia \\ E-mail: abidhayatkhokhar@hotmail.com \\ Zaira Wahab \\ Iqra University, Karachi, Pakistan
}

Received: 30-04-2013

doi:10.7575/aiac.ijalel.v.2n.5p.20
Accepted: 04-06-2013

Published: 01-09-2013

URL: http://dx.doi.org/10.7575/aiac.ijalel.v.2n.5p.20

\begin{abstract}
Poetry is one of the chief ingredients of the textbooks taught in the classes of language as well as arts that appeals to our senses in several domains. Imagery in poetry bears pictographic impact on the minds of the readers. This study aims at finding out what kind of imagery and images are employed in the book and how far they succeed in bringing about pictographic impact on the minds of the students. Content analysis of the poems in qualitative paradigm was adopted for this study. Direct and indirect interviews of the students were also conducted. It was found out that the poems of the book contained all pervasive versatile imagery. Moreover, the images and imagery had verbal as well as visual impact on the minds of the students that helped them improve their memory, increase their vocabulary, enhance comprehension, and develop interest in reading.
\end{abstract}

Keywords: Development, Pictographic, Impact, Poetry, Textbook, O'level, Pakistan

\section{Introduction}

Poetry falls in the arena of art and all art is imaginative. If the real world is beautiful, art transforms it into par excellence. This excellence takes birth in the minds of the poets and shifts into the brains of the readers depending upon the success of the poet. Imagery helps the readers visualize the poems that build mental pictures - a permanent source of learning language and enjoying the piece.

Painting is silent poetry, and poetry is painting with the gift of speech [Simonides $556-468 \mathrm{BC}$ ]. Hence the poetry embellished with imagery can rightly be called poetry appealing to our senses. Such imagery imprints images in our minds. Morphologically, right-brain dominant learners are not primarily verbal. The stronger the image in their mind, the more important the concept is to them (Major, 2012).

Now the question is what sort of images does a poetic piece contain? They not only appeal to our eyes or mental eyes but also have appeal to other senses. The images can be visual, auditory, olfactory, gustatory, and tactile and such they appeal to five gates of knowledge. Some images pertain to locomotion and these images are called as kinesthetic images. Some are images are literal, some are organic and some are conceptual. This division and subdivision is mechanical but their artistic use renders a piece of poetry quite impressive that may last for a long time in our minds.

\section{Literature Review}

Plato propounded "wax tablet" model for memory. According to it, copies of perceptions and thoughts get impressed as images on the tablet. Aristotle, however, opined that images operate as inner pictures as copies of real things and resemble the original thing. In De Anima, he suggests that recalling the pictures by the use of mental images is the practice of mnemonics (427b). To him, 'the soul never thinks without mental image'. Hence, we may conclude form these Greek masters that thoughts depend upon mental images. Descartes distinguished between 'imagining a thing' and 'conceiving of that thing'. Locke the British Empiricist philosopher went pro-imagist and defined memory as the storage of images. He declared language learning as the coordination of sounds and images.

Beginning in late 1970s, there had been virtual explosion of experimental research about imagery. Comprehension, memorization and imprinting of images on mind can further be increased by various factors that relate with teaching and learning techniques e.g. readability, context effects, context familiarity (Sadoski et al., 1993). Imagery heightens the impact of comprehension and understanding of the language as well. It is a great help in learning language as well. Imagery increases the understanding of sentences, paragraphs and passages 'when mental images are formed' (Anderson \& Kulhavy, 1972; Pressley, 1976). Students outperform subjects if they are provided with pre-learning instructions that generate verbal or imaginational schema. Training children to construct mental images increases their ability to draw inference, make predictions and instantly memorize they have read (Gambrell 1983; Pressley, 1976). 
Constructivism proposes that meanings are constructed from experiences and interactions with one's environment. Hence meanings are constructed by the readers.

In the second half of the $20^{\text {th }}$ century, depictionalist school of thought maintained that mental images were stored in an image like format. On the other hand, descriptionalists believed that cognition depended on multiple representational systems. This debate lead to "dual coding theory": the words were represented in the brain through both verbal codes and the visual codes. (Allan Paivio, 1960) He further found that concrete words were far more likely to engage the visual codes than the abstract words. So, the readers could comprehend and remember the information stored in two codes rather than one. When encoded verbally as well as nonverbally, the information was much elaborate. It promoted increased comprehension and strengthened traces of memory as well (Sadoski et al. 1993, p. 291). It helped the students comprehend in a better way because the information stored in mind was twice in effect.

Some people experience images more than others. Sir Francis Galton surveyed university students in 1883 to recall to the items at their breakfast tables. It affirmed that some people mentally see in a better way than others. Furthermore, women were stronger imagers than men. This visual quality is useful in the understanding of the text. Downey (1912) studied how subjects used imagery to represent in texts. To him, visual imagination is a key component of the reading experience that contributed to our understanding of the text.

Centre, Freeman, Robertson and Outherd (1999) proposed that teaching children to construct mental images as they read enhance their ability to generate inferences, make predictions and remember what has been said. Sadoski and Paivio, (2001) explained the inner mental experiences of images that appeared to be captured, organized, stored, and retrieved in the form of background knowledge included visual, auditory, haptic, gustatory and olfactory modalities.

Literature comprises mere words. If there is any imagery, it rests inside the readers (Adorno, 1997). Thus readers, not texts are responsible for creating images. Mental images are artefacts produced by the reader, not the poem (Richard 2001). Consequently, we may say that a poet should employ the images that arrest the minds of the readers and for this he has to fix the audience and the level of audience he is addressing to. Do the poems selected in the textbook, English Alive, befit this situation is a question to answer.

Using toolbox of images is so much important and entailing in the history of English poetry that the modern and post modern poets, critics, teachers and students are lost into the debate whether imagery is inside the poetry or is it imagery that forms poetry. Hard, concentrated and clear images became hallmark of the modern and postmodern poetry with the imagist poets. Joseph Frank (1991) claimed Imagism 'opened the way for later developments by its clear break with sentimental Victorian verbiage'.

Imagism was no longer a movement or idea, it had shaped the form of a cult of imagist poets and being away from which meant to pass away without getting recognition as poet in literary circles. Krog, Jacob (2001) declared that 'no theories or rules [alone] make poetry'. Hence tool of imagery in the hand of imagists worked with so versatility that all the new poetry forgot rhyme and original forms of poetry in the religion of newness and quaint.

English Alive has emerged in Pakistan as one of the textbooks for the students of O'level to prepare for the examination of GCSE conducted by Cambridge University. As the role of poetry is tremendous in the field of teaching language, so the researcher has tried to investigate to what extent can the images of the poetry portion of English Alive play their role. For this, the researcher tried to find out the answers of the following research questions on the basis of this literature review, his experience of teaching poetry and students teachers preconceptions:

1. How many kinds of images do the poems contain in the book?

2. What of impact do these images exert on the minds of the students?

In continuation to the above, the researcher conducted initial interviews with the teachers and the students and developed following sub-questions:

i) Does imagery play any role in memorizing capability of the students?

ii) Do all the images work alike on the minds of the students?

iii) Does imagery improve the capability of increasing vocabulary in the students?

iv) Does imagery of the book only appeal to visualization or has any effect on other four senses as well?

v) Do conceptual images play the same role on the minds of the students as perceptual ones?

vi) Does imagery play any role in improving reading among the students?

vii) Is there any difference of impact of imagery on the minds of the different students?

viii) Does imagery casts different sorts of impact on the minds of the students with different techniques.

ix) Does imagery work better by representing imagery in visual parallels?

\section{Methodology}

Content Analysis was opted as major research design and scanning method had been used in this study. Prior to this project, Pilot study was executed and interviews were conducted in this context. Keeping discrete and holistic view of the poetry, all possible categories of conceptual, perceptual, literal, natural and organic images of the poems were counted through a research instrument. The checklist further subdivided perceptual imagery into visual, gustatory, tactile, auditory, olfactory imagery as sub-categories. Hence, the research instrument contained all kinds of possible imagery to be counted by means of tallies. 
In addition to it, the researcher interviewed 100 students of O'level individually as well as in groups. Great care was maintained not to let them know why these interviews were conducted so that original census could be had from them. The researcher gathered information from the interviews in a random way but organized the answers in systematic order. It was a painstaking job but it was necessary to describe in a logical order.

\section{Reliability \& Validity}

The researcher tried his best to maintain reliability and validity. For this purpose, he tried to adopt fool proof procedure. For exact enumeration of each category and sub-category, all the poems were xeroxed in eleven sets in triplicate. Every theme was sorted out in every line of the poems with the highlighters of specific color for a certain category and was marked into a tally on the research instrument. Finally, all these tallies were counted and transcribed in numeric form on the research instrument. The researcher got assistance from two other sub-researchers who helped him prepare the same work at their own workplaces. Unimaginably, three of us found the same results with a negligible difference. Even then, the average reading was counted as the final one. All the data was fed in Microsoft Excel Program to find exact numerical applications and bring about foolproof graphs, tables, indices and pie-charts.

\section{Results}

The researcher collected data and subdivide the results in two categories. In the first category, he presented the results of the content analysis and in the second, he arranged the results of interviews in a stratified order.

\subsection{Textual images}

Analysis of the poems of the textbooks shows that there is hardly a poem that has no imagery in it. Total 1230 images were found in the poetry portion of the textbook.

The least most images found in the book are olfactory images and the gustatory images falling to be 5 and 20 respectively. Kinesthetic and Visual Images are at their apex i.e., 218 and 180. Tactile and Auditory Images were in middle range i.e. 40 and 52 respectively. Conceptual, literal, natural and organic images numbering 300, 211,110 and 94 did overlap but they proved employment of variety of images in the textbook. It shows that the poems made students infer different ideas and poetic synthesis at their own level.

In the nut shell, every poem whether long or short, was fully embellished with images. They appealed to five senses and made cognitive frame work to probe conceptual as well as literal meanings out of them. Hence, we can conclude that the poems in the textbook are a good help in making the students 'picture as well as intellect smart' by means of versatile imagery in the poetry portion.

Data collected was fed into Microsoft Excel programme. Frequency of each image was decrypted into descriptive mode. Every category was further explained in percentage to as detailed in the following table:

Table 1. Data Analysis of Imagery

\begin{tabular}{|c|c|c|}
\hline Categories & Frequency & Percentage \\
\hline Literal Images & 211 & $17.15 \%$ \\
\hline \multicolumn{3}{|l|}{ Perceptual Images } \\
\hline - $\quad$ Visual Images & 180 & $14.63 \%$ \\
\hline Gustatory Images & 20 & $1.63 \%$ \\
\hline Tactile Images & 40 & $3.25 \%$ \\
\hline Auditory Images & 52 & $4.23 \%$ \\
\hline Olfactory Images & 5 & $0.41 \%$ \\
\hline Kinesthetic Images & 218 & $17.72 \%$ \\
\hline Natural Images & 110 & $8.94 \%$ \\
\hline Organic Images & 94 & $7.64 \%$ \\
\hline Conceptual Images & 300 & $24.39 \%$ \\
\hline Total: & 1230.00 & \\
\hline
\end{tabular}

It was observed that every image was found in the poetry portion of the book. No poem was without imagery. Most of the images were found under the category of perceptual images and out of these perceptual images, we found that visual, kinesthetic and natural images were more in number. Similarly, sharp number of literal and conceptual images showed that the images in the poems not only could make the students vision and sense smart but would help them employ their cognitive framework effectively.

\subsubsection{Images in mind of students}

In solo interviews of the students, it came into notice that they responded $30 \%$ to $40 \%$ images of each poem. This percentage had a sharp increase when the same question was asked in the form of groups. They responded 80 to 90 percent images when interviewed in groups with the homely atmosphere of consulting others like discussion sessions in playgrounds, canteens, libraries, corridors and sometimes in the classrooms when they were free. Out of 1230 images, 
the researcher had enumerated in his content analysis of the poems, the students mentioned 974 images in their interviews and discussion to which he had been extremely observant in his predesigned process of research. When discussed poem by poem, the following images came forth from the ready memory, labored memory and consulted memory of the students.

1. Pathos provoking image of a wife hiding behind the trunk of an oak tree made one of the female student say that it was a stunning image to her when there were multitudes of people around the funeral of persona of the poem Doc Hill.

2. The poem, I am a Camera proved to be the jacket of the poetry portion of the textbook through the interviews of the students that concentrated on watching, looking, capturing and storing the sights and scenes exactly as they are. The students amazed on the contrivance of the paragraph of a novel into the lines of the poem. They told the researcher, there is something special in these lines that made the editor place in the textbook on prominent position. Moreover this novel had got approval of the masses in cinema scope and theatre as well.

3. 'Dark charming face' of a young girl 'Amidst the Traffic Lights' passes by 'Jungle shaking earth quaking truck horns' to sell towels made the researcher boosted enough and convinced him that it left an indelible mark on the minds of the students in an impressive way.

4. Spirit of self-resignation by Christopher Logue in 'London Airport' was source of applaud to the poet by some students who throws his poem in the 'bin labelled UNWANTED LITERATURE'.

5. Many students reported that they had never thought about geography aspect of earth as a globe and their position with respect to earth especially 'six miles high' before reading Zulifqar Ghose's poem Geography Lesson.

6. Some students reported that they couldn't understand the poem if their teacher and the illustration in the book had not been there to explain the brief poem A Narrow Valley that expresses floods in terms of falling 'A bowl of milk' from the hands of 'a trembling child'. It made them realized their real position in the cosmos by Daud Kamal and their actual status in the hands of nature.

7. Gross number of students appreciated imagery of the poem Night of the Scorpion. They couldn't forget gathering of the peasants 'like swarms of flies' when the mother of the poet was bitten by a scorpion in her house of 'mud baked walls' and collective efforts of the people with 'powder, mixture, herb and hybrid'. They hailed honours on self-scarifying nature of mother who thanked God on pricking of the scorpion on her and 'spared her children'.

8. Imagery of seven stages propounded by Shakespeare was also applauded by the students especially 'mewling and pucking in the nurse's arms', lover's 'sighing like a furnace and 'sans teeth, sans eyes, sans taste, sans everything'. Few of the students said that the last line made them scrupulous enough in their behaviour.

9. Students reported that the images and imagery in Mohejo Daro is profuse. They couldn't forget uncovering of the city 'brick by brick', 'ponderous heads and curving horns on seals', 'metal bangles, jingling even at rest', wide hipped Earth Mother, skeletons lying criss-crossed and spreading of flood of black water. Few of the students reported that they felt shy when they visualize the image of 'wide hipped' about mother.

10. The imagery for different societies of 7000 years ago visualized by a girl in glass made the students infer the ancient life and culture in the poem "In a Dark Stone". Flint mines, brass and gold, bronze cauldron, statues and slabs of stone were reported to be the images that were still in the minds of the students.

11. Carpet Weaver was declared a beautiful poem by the students. It was fanciful to them because this workman in their cultural heritage was invisible altogether but had much enough detail in the poem to visualize him. Nook, 'His fingers blunt with wool', 'ancient contraption', 'scurry of a rat', 'knots per square inch', muezzin's call, 'rice-dheges and strings of flowers' and the last line 'Recommendations work even here' made them fond of this poem. It showed local and cultural images and trends to them.

12. Slipping away of idea through the poet's fingers in "Empty Head", handling carefully the thought like a saucer of milk in "Shallow Poem" and shrinking and growing of the poet and the poem in "My Poem" made the students realize some abstract truths in concrete terms.

13. Majority of the students liked imagery in the poem, Hawk Roosting. Falsifying dream, hooked head and hooked feet, perfect kills, air's buoyancy, sun's ray, earth's upward face for inspection, rough bark, flying up and revolve, no sophistry, tearing off heads, allotment of heads, direct flight, to have sun behind were the images the students mentioned being fresh in their minds.

14. Many of the students reported that drumming of the scarlet soldiers in the poem "O What is That Sound" left fresh imagery of flashing light, usual manoeuvres, kneeling of the viewer and wheeling of the order, none of them being wounded, passing and running through farmyard of cunning farmer, deceiving vows, heavy boots and burning eyes.

15. Very few students, who seemed to be bright enough, intelligently protruded the imagery out of the poem, Specimen. They remorsefully exclaimed man as a rarest specimen. Their bones in museums, Hunting of them for sport, six wolves to the hunt, increased size of their weapon and decreased size of their brains, leaving of their children helpless, dumb humans behind the bars and watering of eyes as a cleansing mechanism seemed engraved onto their minds.

16. Approximately all of the students enjoyed the imagery in the poem "Circle" in which a white man and Indian draw a circle and explain cosmic truth about the amplitude of knowledge of the man in a simple action.

17. Jenny Joseph's Warning also made students express about the old age in a cautious tone. They said that this poem left the images of precocious alarms through wearing of purple, spending of pension on brandy (with an 
expression of awkwardness), satin sandals, sitting down on pavements, gobbling up of samples, pressing of alarm bells, running of stick along the public railings, picking of the flowers, hoarding of pens and pencils, learning to spit, paying of the rent, inviting friends to dinner, reading the papers.

18. The images of 'veins like small fat snakes', 'unstrung onyx beards', 'helplessly old' and 'helplessly young' in the poem "Childhood" proved quite fresh in the minds of the students.

19. Aunt Julia and the poem titled by her name had interesting imagery for the students. They told the details of her very loud speaking of Gaelic, wearing of men's boots, her strong foot stained with peat, paddling with the treadle, drawing of her right hand out of the air, listening of crickets, keeping of three penny-bits in the teapot and lying silenced in the sandy grave.

20. An abstract phenomenon in the poem "Get off this Estate" was recollected by the students through concrete images of having estate from father of the father who got it by war- craft.

21. To the extent of the researcher's astonishment, great number of students showed interest and command over explaining plain and symbolic imagery in the poem "Buy My Flag" through the person of an 'Exhausted' chap. 'Fourteenth of August', 'glamour of the flag through hard metal', 'turning wheels', 'choking fumes', 'star studded green and white flag' like 'summer grass and jasmine', 'trees and icy river foam', 'dream of grasping ten rupee note', 'searing flames of engine heat', 'hellish gnawing need',' Full stomached sleep' and their symbolic interpretation with Socratic irony made the researcher evaluate the imagery to a higher level.

22. In the poem "Lineage", following plough, bending to toil, sowing seeds, growing of grains with the touching the earth smelling of soap and onions and wet clay makes students imagine the grandmothers of the poet as a strong and unique predecessors. The imagery of 'veins rolling roughly over quick hands' made students reminded of the old-woman of Frances Cornford's poem "Childhood".

23. Grandfather's Bridge by Kaleem Omar is another poem laden with local, general, provincial and natural imagery of the countrymen. The students went on enumerating rock halted slope, rush of water, monsoon flood, concrete pieces, unexceptional town, honest reputation, several promotions, concrete arch, monsoon sky, flooded stream, central provinces, subsequent techniques, gamble work, walking up and down, with his stick, hovering of the men anxiously and saying of him "Build here" and finally going to the railway station and waiting for the train.

24. The students recollected the images of beasts and trees, Bukhara carpet, elegant samovar, aroma of green tea, reflections of absent friends, taking off muddied boots in the poem Exile of Daud Kamal with laboured memory.

25. Hiding alone in the corner and hugging Fatima Bhutto herself with pain, pity and pathos out-shows her alienation as reported by the students in "I Throw Myself".

26. Many of the students had not reached up-to "The School Boy" but those, who had read it, reported that the imagery of summer morn, singing of birds, distant huntsmen, skylarks, sweet company, all joy away, cruel outworn eye, sighing and dismay, drooping sit, anxious hour, learning bower, dreary shower, sin in the cage, annoying fears, tender wing, youthful spring, mellowing year and blasts of spring lurks in their minds and eyes.

27. Similarly the imagery of "Schoolmaster" was quite impressive to the students. Mentioning of white trees, looking out of the window for a long time, breaking of the chalk piece, going away of the wife, wearing of oldfashioned suit, fumbling his hand in pocket, rubbing his forehead about the ticket and creak of the door made them relaxed in summing up the imagery they had in their mind for the poems in their text book.

4.2.2 Interviews on imagery

In addition to knowing the extent of imagery preserved in the minds of the students, other questions regarding imagery, learning of imagery, benefit of imagery and the role of teacher as well as methods of teacher to teach imagery were indirectly and obliquely asked about. Summary of these interviews is as below:

i) The researcher noticed that the students used to forget a lot of images in the poem but they recollected sharply when other friends of them mentioned the images they had in their mind and vice versa. It pointed out that the images that had gone in the background of the student's memory got refreshed and they brought forward other tumult of images during group work or discussion. In addition to it, the students who had been listening to the speaking class fellows helped a lot in recalling other images what the active students had not been recalling at all.

ii) In the end of the discussion, the students told that the interviewing had been a healthy influence on them and they would try to maintain images in future. Some of the students of other schools, when met with the students of the previous schools and cross exchanged their interviews, complained that the way of explaining the poems of their teacher was not so impressive like that of the others. That is why the storage and recalling of the images and imagery to them remained poor.

iii) The students reported that the new vocabulary what they did learn through imagery of the poems was easy, lasting and less laborious. They reported that in such an activity they not only learnt new words and phrases but also found many cross referred words and phrases which automatically memorized along with their background knowledge. They confessed that the credit of the most of the part of this healthy activity goes to the teacher who presented poetic material in an effective way failing which it had been otherwise altogether. 
iv) Another supplementary remark came on the part of the students that there was such a variety of imagery in the poems that they not only saw through images in a better way but found words that appealed to their sense of touch, smell, sight, listening, taste, movements, and understanding.

v) Some students complained that few conceptual images had been difficult for them but on the same time they added that they were presented by the students of other classes in a better way. It gave another clue that acquiring the meanings of the images did not only depend upon the reading of the students but was variably dependent upon the style, competence and interest of the teachers as well. Hence, it is recommendable that such teachers should be employed on the task of teaching poetry who are motivated and resourceful enough in the field of teaching poetry.

vi) They proclaimed that reading poetry and concentrating imagery had been an interesting activity. They learnt new ideas, got new vocabulary and developed interest in poetry not in a thrusting way, but in a homely atmosphere.

vii) Lots of the students narrated if their teacher had not presented poems in an effective way, they might have been groping in the darkness. They would have failed in conceptualizing the abstract concepts what they do understand now in tangible, easy and clear terms only because of their teacher's versatile genius.

viii) Another byproduct of these interviews with the student revealed the researcher that reading poems with enjoying imagery again and again increased their competence of reading, understanding and comprehension to a higher level. When questioned, "How much?" they reported more than $50 \%$. So, we may rightly conclude that pictographic impact of the poetry on the minds of students is tremendous enough in reading as well.

ix) The students also reported that rhythmic and phonic flow in the form of alliteration, assonance, consonance, repetition supplemented with images in the poems not only improved sound and sense to our ears and minds but also promoted linguistic fluency and improved a vast range of writing as well. It was so because they had found good store of astounding phrases, striking statements and quotable quotations.

\section{Discussion}

The very first poem 'I am a Camera' looked as if it were the jacket of the whole poetry portion of the book. On the part of content and meanings, it showed tremendous potential in it. Originally, it had been a paragraph selected from Christopher Isherwood's novel Goodbye to Berlin and had been beautifully turned into poem. It shows if something is depicted with perfect, concise, clear and concentrated images, formal embellishments of the poems go on the background and originality as well as novelty becomes poetic in itself. This aspect conforms to imagists' theory.

The editor of the book might have consciously placed this poem in the beginning to tell the readers that the poets behave like detached observers and depict through images, not comment. The words we read and the images we see are not the abstractions of reality. Imaging or the act of experiencing mental images is connected with senses. When an image is crafted skillfully and read by a solemn reader, we see a vivid picture in our mind's eye, or we hear a recognizable sound in our mind's ear, or we smell a certain scent and the like. In this way, all the faculties of sense respond in the mind of the readers. Powerful images, clear sounds, poignant smells, melodious music imprint on the minds like engraving. Producers of visual media know a single compelling image is hard to erase (Wax Tablet Model). Images are really powerful.

Images also have aesthetic element as an integral part of artistic work. We see the world in new different ways. Participation with works of excellent features is considered as artistic produce and they make the aspects of world more vivid. We had the opportunity to be awakened from our stock responses to a stance of what Green (1978) called 'wide awakeness'. Similarly Eisner (1998) believed that the artistic treatment of any form of representation was a way of creating an impact of making ideas and images clear. Images made certain kinds of experiences, because the ideas that became fixed in a public form were not only realized by the creator but were stabilized, refined, edited and shared with the potential of influencing others to be enjoyed (Romano, 1998).

Students learnt a great deal from poetry in general and images in particular. Language and images were inextricably linked. Use of images or imagery was a primary underlying structure in language, media and mind. They linked with speech and verbal text (Rosenblatt, 1978). Images flashed upon the mind the way lightening flashed upon the earth and illuminated the entire landscape in a moment that had been hidden altogether (Zitlow, 1997). The students thought in flashes and busted of images, in descriptive fragments that were like "Lights in the Windows".

Mental imagery means any image created in the mind without the presence of real object or event including the images of sight, sound, taste, touch, smell sensation and feelings. Winograd and Bridge (1989 ) maintained that imagery included memories of sights, sounds, tastes, touch, smells feelings, events and stories that may replay in the minds.

There was variety of images in the books. Total 1230 images had been used in 33 poems of this book (4.1). An average poem had 37.27 images involved in representing the subject matter of the poet through his experience. Imagery used in these poems was versatile including perceptual images i.e. visual, gustatory, tactile, auditory, olfactory images (4.1). Each poem was unique like a person or a place and should be considered as such. According to Duel Coding theory, 
images combined verbal and non verbal cognition into a unified framework. Images (non verbal) combined with the language (verbal) worked more forcibly on minds than precepts. This theory explained the inner mental experiences of images that appeared to be captured, organized, stored and retrieved as background knowledge along with visual, olfactory, haptic (touch), gustatory and olfactory senses (Sadoski \& Paivio, 2001). Hence, the book offers the material of images widely ranging to all senses that may helped them benefit with pleasure to an extensive range.

Many people thought mental imagery as a visual imagery. They called them "pictures in mind" (Gambrell \& Bales 1985). Sadoski and Paivio (2001) said that there was a "mind's eye". Side by side with "mind's eye", there was "mind's ear" and other senses of mind. Douville and Algozzine (2004) declared that mental imagery served as a kind of internal blackboard or personal movie screen that aided in dynamic problem solving of verbal and spatial tasks. Sadoski (2005) declared imagery as "primary cognitive form of nonverbal representation".

Furthermore literal images, kinesthetic images, natural images, organic images, and conceptual images were also sparsely visible like the cake pieces in the poems. No kind of image was left unused in the poems. They extended the range and canvas of the minds of the students. The interviews with the students showed that all the variety of images was not only found in the poems, but were also reported by the students. Variety of these images made students improve and appeal their variety of intelligences and helped them to be picture smart, nature smart, person smart, logic smart that refers to 'theory of multiple intelligences'.

i) The above images cast a healthy influence on the minds of the students. Picturesque quality of them helped them memorize and visualize simultaneously at double level. It enhanced their ability to generate, infer, make predictions and remember what had been said (See 4.2.1) It not only improved the memory of the students but strengthened enough to imprint on the minds of the students. Double coding theory (Sadoski et al. 1993) supported this evidence. Moreover real impact of imagery was not on the part of the poet but its scope of work was for the reader. Hence, the reader was not instructed to understand but the reader himself constructs the pictures in his mind. Mental images were the artefacts produced by the reader, not the poem. (Richard, 2001)

ii) When interviewed individually, the images reported by the female students were $15 \%-20 \%$ more than the male students. Sir Francis Galton surveyed university students in 1883 to recall to the items at their breakfast tables. In his study, it was also reported that women were better imager than the men. Hence female students were mentally better seer in degrees than the men and impact of imagery on them was naturally better than the men. On the other side, some students reported better number of imagery than the rest but its range differed with respect to their competence, background knowledge and personal trends. Few of them were less vocal and reported few but gave excellent clues in group interviews. Hence, some people experience images more than others.

iii) Downey (1912) studied how subjects used imagery to represent themselves in texts and propounded that visual imagination was a key component of the reading experience that contributed to our understanding of the text. The student's interviews, either individually or collectively, determined that their level of learning vocabulary got better with reading, learning and understanding of imagery. It helped them visualize the images by finding close parallels of them. Natasha Trethewey, American Poet Laureate, went besides herself when she noticed saying her young daughter of 06, 'small tree' to 'broccoli' because she being a poet knew that her daughter had been finding parallels between the original and metaphoric object. It showed the depth of her observation. The words were represented in the brain through both verbal code and the visual code (Allan Paivio, 1960). So, imagery provided the students new vocabulary in a better and effective way by finding parallels between the real object and the imagined one.

iv) There was variety of all sorts of images in the poetry portion. The images reported by the students in interviews were not only the visual images but the others as well that appealed to touch, taste, audition and olfaction. The students were inflated enough in reporting the images that appealed to different senses of their mind. Sadoski and Paivio (2001) propounded and explained the inner mental experiences of images that appeared to be captured, organized, stored, and retrieved in the form of background knowledge including five gates of knowledge i.e. visual, auditory, haptic, gustatory and olfactory modalities. This study confirms that the images have versatile impact on sound and senses of the students. They can contrive literal, natural, kinaesthetic and conceptual images out of them as well.

v) Training children to construct mental images increased their ability to draw inferences, make predictions and instantly memorize they have read. Pressley (1976) and Gambrell (1983) also had propounded the same. The students were well versed in concrete images. As far as conceptual images and the images for abstract nouns were concerned, they did not find the same level of felicity. Even then, imagery and images explained abstract and conceptual images better than bare words and phrases because level of difficulty also increases in learning them in traditional ways. The students reported that some teachers were good in constructing concepts through images (4.2.v). This aspect needed great care and concern from the educational leadership to render effective teaching. Furthermore, constructivism (meanings are constructed from experiences and interactions with one's environment) brought about virtual explosion of experimental research about imagery.

vi) Imagery heightened the impact of comprehension and understanding of the language as well. The students reported that imagery in the poems helped them a lot in understanding, reading and comprehension (4.2.vi). Imagery and interest were reciprocal to reading and it was imagery that lead reader not drop the book off his sight until it got finished. It was a great help in learning language too. Imagery increased the level of understanding of sentences, paragraphs and passages when mental images were formed. Anderson \& Kulhavy (1972), Pressley (1976), Centre, Freeman, Robertson and Outhred (1999) opined that teaching children to construct mental images as they read enhanced their ability to 
generate inferences, make predictions and remember what had been said. Images involved the reader into the book to a deeper level. He went on constructing visual parallels in his mind. Hence, he read the book not but watched scenes, sceneries, actions and montages. Many a student reported that they couldn't leave reading a book until and unless it got finished. On probing, it came to know that such books were the books that contained literary material laden with images and imagery creating imagination in them. So, we may say that imagery helped in increasing reading capability as well.

vii) Distinct impact of imagery on the minds of students was observed. The students complained that few teachers had little capacity to let students also enjoy and entertain with images and imagery. Naturally, this disharmony could cast an anomaly effect on the minds of the students. The educational leadership should have been serious enough in selecting the equipped and resourceful faculty on standard norms so that homogeneity in achieving the targets in educational institution could be brought about.

viii) Another important factor that had a noticeable effect of the impact of imagery on the minds of the students was teaching tactics and technology. Some teachers used multimedia and made their lessons more attractive. In addition to that, their way of presentation was so mature that the students reported that the other teachers couldn't do that in other classes. Comprehension, memorization and imprinting of images on mind could be increased by various factors that related with teaching and learning techniques e.g. readability, context effects, context familiarity. Sadoski et al. (1993) had had a research in the same context.

ix) Striking impact of imagery was noticed that worked more forcibly on the minds of the students when unaided by visual parallels. Some of the students complained that they enjoyed imagery in a better way than the lessons executed on multimedia and visual material. They said audio-video aids corrupted the scenes and objects they had created in their minds before watching visual presentations of them. This aspect of impact of imagery needed a special research as to know how that happened in the minds of the readers. Hence, visual parallels and cinematography damaged the conceiving of images through the faculty of imagination. It supported the idea of constructivism against conservatism in imagery. Conceiving, analyzing, and perceiving an image was a constructive theory in which the minds of the reader developed his own pictures.

\section{Conclusion}

In view of the above, it may rightly be concluded that

a. The poems of the book English Alive contained all pervasive versatile images to the sense and sanity of the students, thereby matching the needs, moods, topics and themes of the present day societies of the world in general and Pakistan in particular.

b. Images and imagery in the aforementioned poetry portion exerted tremendous impact on the minds of the students helping them improve their memory, increase their vocabulary, enhance comprehension and develop interest in reading as well as deriving aesthetic pleasure in them.

\subsection{Recommendations}

1. Curriculum for teaching English language should be supported with the textbook containing the poems having all pervasive imagery relating with real culture and social conditions of the natives or the foreigners that may ensue students acquire, learn language and literature.

2. Special pre-teaching training for the teachers of teaching poetry can ensure creating images in the minds of the students failing which this activity can prove otherwise.

3. Special kits, interactive board and multi-media can add effective utility of bringing pictographic effect in teaching and learning of poetry.

4. Ignored role of poetry in EFL, TESOL, ESP and other prgrammmes of teaching English may be revitalized that can bring about better results in light of the above study.

5. A cult of discussing images in the students as well as teacher should be produced by the peer administrators by exchanging their beliefs, experiences and knowledge.

\section{References}

Adorno, T. W. (1997) Aesthetic Theory. Ed Gretel Adorno and Rolf Tiedemann. Minneapolis: University of Minnesota Press.

Anderson, R. C., Kulhavy, R.W. (1972). Imagery and prose learning. Journal of Educational Psychology, 63, 242-243

Benton, P. (1999). Unweaving the Rainbow: poetry teaching in the secondary school I .Vol. 25, No. 4 (Dec., 1999), pp. 521-531. Oxford Review of Education. Taylor \& Francis Ltd. Abingdon.

Benton, P. (2000). The Conveyor Belt Curriculum: Poetry teaching in the secondary school II. Vol. 26, No. 4 (Dec., 1999), pp. 521-531. Oxford Review of Education. Taylor \& Francis Ltd. Abingdon.

Bohn, W. (2001). Modern Visual Poetry, Newark: University of Delaware P. Cranbury, NJ.

Brooks, C. \& Warren, R. P. (1950). Understanding poetry rev: Ed. New York: Henry Holt. 
Center, Y., Freeman, L., Robertson, G., \& Outhred, L. (1999). The effect of visual imagery training on the reading and listening comprehension of low listening comprehenders in year 2. Journal of Research in Reading, 22, 241-256

Chall, J. (2000). The academic achievement challenge: What really works in the classroom? New York, NY: Guilford Press.

Coffman, S. K. (1951). Imagism: A Chapter for the History of Modern Poetry. University of Oklahoma Press. 1st edition (1951). Noman.

Collins B. C. (2001). Teaching the language arts: Expanding thinking through student-centered instruction. (2nd ed.). Boston, MA: Allyn \& Bacon.

Douville, P. (1998). Bringing text to life: The effects of a multi-sensory imagery strategy on fifth-graders' prose processing. Research report presented at the $43^{\text {rd }}$ Annual Meeting of the International Reading Association, Orlando, Fl.

Downey, j. E. (1912). "Literary Self Projection."Psychological Review. 299-311

Dunn, L. M., \& Dunn, L. M. (1997). Peabody picture vocabulary tests. 19, (3 ${ }^{\text {rd }}$ ed.). Bloomington, Pearson Assessments.

Eisner, E. (1998). The Kinds of Schools We Need: Personal Essays. Portsmouth, Nh: Heinemann.

Frank, J. (1991).The Idea of Spatial Form. New Brunswick. NJ: Rutgers UP

Gambrell, L., \& Jawitz, P. (1993). Mental Imagery, text illustrations, and children's story comprehension and recall. Reading Research Quarterly, 28, 264-276.

Gambrell, L. B. (1983). Induced mental imagery and the written language expressions of young children. In J. A. Niles (Eds.), Searches for meaning in reading/language processing and construction $\left(32^{\text {nd }}\right.$ year book of the National Reading Conference, pp 251-254, Rochester, NY: National Reading Conference.

Gibson, U. T. (2008). A Level-Headed Means to Evaluate Poetry. On Judging Poetry, Retrievable at http://www.chaparralpoets.org/judging.html

Green, M. (1978). Landscapes of Learning. New York: Scholastic.

Heard, G. (1998). Awakening the Heart: Exploring Poetry in Elementary and Middle School (p.62-72). Portsmouth N.H. Heinemann.

Hinkel, E. (2005). Handbook of Research in Second Language Teaching and Learning, (edited), Lawrence Erlbaum Associates.

Hinkel, E. (2005). Culture in Second Language Teaching and Learning. Shanghai: Shanghai Foreign Language Education Press.

Howard, G. (1989). To Open Minds: Chinese Clues to the Dilemma of American Education. Basic Books. New York. Jones, P. (1972). Imagist Poetry. Penguin. London.

Korg, J. (2001). Imagism. A Companion to Twentieth Century Poetry. Ed. Neil Roberts. Oxford: Blackwell, 127-137

Locke, J. (1690). Essay Concerning Human Understanding, The Pennsylvania State University.

Major, S. (2012). The Impact of Hemispheric Dominance on Learning to Read. Retrievable at http://www.homeeddirectory.com/blog/impact-hemispheric-dominance-learning-read Submitted by Sarah Major (not verified) on April 16, 2012 - 12:35pm

Nica, M. (2011). Teaching Poetry to Undergraduate Students. Elsevier Ltd. Ploiesti.

Paivio, A. (1965). Abstractness, imagery, and meaningfulness in paired-associate learning. Journal of Verbal Learning and Verbal Behavior, 4, 32-38.

Paivio, A. (1969). Mental imagery in Associative learning and memory. Psychological Review, 241-263

Pike, M. (2000). Keen readers: Adolescents and pre-twentieth century poetry. Educational Review, 52(1), 13-28.

Pound, E. (1915). Some Imagist Poets: An Anthology. Boston: Houghton, 1915.

Pressley, M. (1976). Mental imagery helps eight-year-olds remember what they read. Journal of Educational Psychology, 68(3), 355-359

Pudewa, A. (2005). Linguistic Development through Poetry Memorization. Institute of Excellence in Writing, Inc. retrieved through http://www.excellenceinwriting.com

Reverend, C. (1983). Teaching Poetry: The negative approach. College Literature Vol. 10, No. 3, First-Decade Issue-Fall, , retrievable at http://www.jstor.org

Richards, I. A. (2001). Practical Criticism: A Study of Literary Judgment. Ed. John Constable. London: Routledge.

Richards, I. A. (1961). Principles of Literary Criticism. New York: Harcourt Brace,

Roeckelein, J. E. (2004). Imagery in Psychology: A Reference Guide. Westport, Connecticut: Praeger,

Romano, T. (1998). "Relationship with Literature." English Education 30:1 Feb; 5-18

Rosenblatt, L. (1978). The Reader, the Text, the Poem: The Transactional Theory of the Literary Work. Carbondale: Southern Illinois University press.

Sadoski, M. (2005). A dual coding view of vocabulary learning. Reading \& Writing Quarterly, 21, 221-223 
Sadoski, M., \& Paivio, A. (1994). A dual coding view of imagery and verbal processing reading comprehension. In R.B. Ruddell, M. R. Ruddell, \& H. Singer (Eds) Theoretical models and processes of reading (pp.582-601), Newark, DE: International Reading Association.

Sadoski, M., Goetz, E. T., \& Fritz, J. N. (1993), Impact of correctness on comprehensibility, interest, and memory for text: Implication for dual coding theory and text design. Journal of Educational Psychology, 291-304.

Sadoski, M, Goetz, E. and J. B. Fritz. (1993). Impact of Concreteness on Comprehensibility. Interest and Memory for Text: Implication for Duel-Coding Theory and Text Design. Journal of Education Psychology, 85(2), 291-304.

Seely, J. (2002). English Alive: A Complete 'O' Level English Programme (Book 1 \& 2). Oxford University Press. Karachi.

Shuman, R. B. (1993). Teach Poetry? Indeed! p.19, Educational Leadership. ASCD retrievable at http://www.ascd.org/publications/educational-leadership

Simonides (556 BC - 468 BC). Silent Poetry. http://www.quotationspage.com/quotes

Sperry, R. W. (1981) Mind-brain Interaction: Mentalism, Yes; Dualism, No. Mobius 1(4), 46-65.

Winograd, P., \& Greenlee, M. (1986). Students need a balanced reading program. Educational Leadership. April, 1621.

Wooldridge, B. R. (2006), The power of perception an activel Experiential learning Exercise for principles of Marketing, Marketing Education Review, 16 (summer),2. 5-7.

Zitlow, C. S. "Paula Fox." (1997). In Writers for Young Adults, Volume 1. Edited by Ted Hipple. New Yourk: Scribners, 413-422. 